MARIUSZ GUZEK

Instytut Nauk o Kulturze

Uniwersytet Kazimierza Wielkiego w Bydgoszczy
Images

vol. XXVIII/no. 37

Poznań 2020

ISSN 1731-45OX

\title{
Czechosłowackie podróże w czasie - od filmowej lekcji przyrody do normalizacyjnej zwariowanej komedii
}

\begin{abstract}
Guzek Mariusz, Czechosłowackie podróże w czasie - od filmowej lekcji przyrody do normalizacyjnej zwariowanej komedii [Czechoslovakian time travel - from a filmed nature lesson to the normalization of crazy comedy]. "Images" vol. XXVIII, no. 37. Poznań 2020. Adam Mickiewicz University Press. Pp. 61-76. ISSN 1731-450X. DOI 10.14746/i.2020.37.04.
\end{abstract}

Aвstract. Czechoslovakian film fantasy has its own canon comprised of various works, the successes of which were recorded by press industries around the world. They picked up various threads, but the most interesting one seems to be the theme of time travel, as represented by three films: A Journey to the Beginning of Time (1955), I Killed Einstein, Gentlemen (1969) and Tomorrow I'll Wake Up and Scald Myself with Tea (1977). They were produced in different production conditions and placed in different genre assumptions, and they referred to the tradition of science fiction developed by popular literature in different ways. The text tries to define their status as part of the achievements of national cinematography, indicate structural components, and briefly discuss their reception, both critical and audience.

KEYwORDs: Czechoslovakian film, science fiction, time travel, crazy comedies, normalization

Czeska krytyka chce rozmawiać o filmowej fantastyce, jednak nie widzi potrzeby, aby uwzględniać $\mathrm{w}$ tych dyskusjach rodzime dokonania. Najlepszym przykładem jest zawartość ostatniego numeru kwartalnika „Film a doba” z 2019 roku, którego dominujący temat brzmi Současné sci-fi - od formy $k$ spiritualite [Współczesna fantastyka naukowa - od formy do duchowości]. Artykuły między innymi Marka Holana, Marka Slováka i Janisa Prášila odwołują się do koncepcji wewnętrznego kosmosu, posthumanizmu i społecznych modeli dyferencji na przykładzie kina głównego nurtu, do którego zaliczona została również fantastyka południowokoreańska[1], ale próżno by szukać $\mathrm{w}$ tych rozważaniach nawet historycznych śladów czeskiego czy słowackiego filmu sf. Kino gatunkowe w Europie Środkowej zawsze było ujęte w ironiczny nawias, ale jednocześnie potrafiło odnajdywać w klasycznych konwencjach takie warianty, które uzupełniały narodową perspektywę. W czeskiej fantastyce szczególną rolę odgrywały bowiem nie podróże międzyplanetarne, bunty robotów czy postapokaliptyczne wizje przyszłości[2], ale

[1] B. Slavik, Jak w žanrovém filmu nevidět všudypřitomnost kopie... - Současné jihokorejské sci-fi na pozadí filozofie diference, „Film a doba” 2019, $\mathrm{nr} 4$, s. 42.

[2] Oczywiście te tematy również poruszała czeska fantastyka - podróże międzyplanetarne (Ikarie XB-1, reż. Jindřich Polák), bunt robotów (Slečna Golem, reż. Jaroslav Balík), świat postapokaliptyczny (Konec srpna v hotelu Ozon, reż. Jan Schmidt). Dość oględne, ale niepomijające najważniejszych komponentów omówienie tych motywów w polskiej literaturze przedmiotu znajdziemy w szkicu J. Trzupka, patrz idem, 
wędrówki w czasie, w które wpisywano z jednej strony popularne strategie narracyjne, a $\mathrm{z}$ drugiej sygnalizowano pozadiegetyczne znaczenia. Zresztą lata powojenne były dość specyficzne także dla czechosłowackiej literatury fantastycznej - od 1948 do 1954 roku można odnotować jej niemal całkowitą nieobecność w czytelniczym obiegu, później, do połowy lat sześćdziesiątych, gdy w dyskursie publicznym pojawiła się rywalizacja rosyjsko-amerykańska tycząca podboju kosmosu, mieliśmy do czynienia z „kosmiczną wiosną” [kosmické jaro] inspirowaną osiągnięciami socjalistycznej kosmonautyki. W 1964 roku twórcy odeszli od „kosmicznych” tematów, by pod koniec dekady zająć się pesymistycznymi utopiami i antyutopiami. W dekadzie lat siedemdziesiątych, czyli we wczesnej fazie normalizacji, ponownie dała się zauważyć atrofia fantastyki naukowej na rzecz literatury dziecięcej i młodzieżowej[3]. Motyw podróży w czasie pojawił się jedynie w kilku opowiadaniach, z czego najbardziej interesujący wydaje się niewielkich rozmiarów tekst Ludvíka Součka Kursk 7/6/43/1207 ze zbioru Operace „kili” (1970). Groteskowy opis bitewnego zachowania radzieckich żołnierzy w kontekście wizyty gości z przyszłości spowodował, iż część nakładu została na żądanie Moskwy wycofana z księgarń[4]. W słowniku literatury sf wydanym kilkanaście lat temu w oficynie $\mathrm{H} \& \mathrm{H}$ zaprezentowane zostały trzy rodzaje stosowania tego wątku w światowej fantastyce:

1) podróż z teraźniejszości w dwóch kierunkach - do przeszłości lub do przyszłości. Ten podstawowy i najczęściej wykorzystywany dzisiaj schemat jest jednocześnie najstarszy i sięga czasów przed powstaniem sf, a ścieżki obu kierunków zostały wytyczone w ramach literackich fantazji przez autorów, których trudno uznać za prekursorów gatunku (M. Twain, S. Čech, W. Irving);

2) podróże, które prowadzą do teraźniejszości z przeszłości lub przyszłości (J. Wyndham);

3) podróże, których charakter określają intencje podróżujących. Mogą być zamierzone lub niezamierzone i odbywają się dzięki fantastycznym środkom jak sen, przeniesienie do innego stulecia lub wyimaginowanej technologii - ożywienie zmarłych, reakcja nuklearna, dylatacja czasu w locie z prędkością światła (G.H. Welles, R. Sheckley, F. Poul) [5].

\begin{abstract}
W krainie Golema i robota - uwagi o czechosłowackim filmie fantastycznym, [w:] Europejskie kino gatunków, red. P. Kletowski, Kraków 2016, s. 209-223. Podstawowym opracowaniem pozostaje monografia zbiorowa wydana dziesięć lat temu pod redakcją I. Adamoviča i T. Pospiszyla, Planeta Eden - Svět zítřka v socialistickém Československu, 1948-1976, Praha 2010, której filmowy rozdział napisany przez Adamoviča Stř́brné komety filmového plátna umieszczony został na stronie $<$ www.fantasyplanet.cz/?s=obrazy\% 2 obudoucnosti\%2Ov\%20ceske\%2ofilmove\%2osci\%2ofi\%201>, dostęp 28.03.2020.
\end{abstract}

[3] Puls nekonečna. Kronika české science fiction 2.

Od Vladimíra Babuly k Alexandru Kramerovi, sestavil I. Adamovič, Praha 2011, s. 11-12.

[4] Ibidem, s. 93.

[5] (jvs), Hlavní motivické okruchy SF, [w:] Encyklopedie literatury science fiction, sestavili O. Neff, J. Olša jr, Praha 1995, s. 114. Warto skonfrontować te literackie kwantyfikacje z filmowymi ustaleniami Krzysztofa Loski. Otóż jego zdaniem zasadniczy dla wyodrębniania poszczególnych narracji o podróżach w czasie jest status i intencje bohaterów, którzy: 1) usiłują wpłynąć na bieg zdarzeń, odwracając historię, 2) pragną 
Kino czechosłowackie postanowiło nie spłacać długu rodzimej literaturze i zaproponowało oryginalną eksploatację tematu[6], choć opartą na podobnej kwantyfikacji narracyjnej. Pavel Gotthardt w dysertacji doktorskiej Skutečný stroj času. Scenáristické postupy v českých sci-fi filmech mezi lety 1918-1989 [Prawdziwy wehikuł czasu. Techniki pisania scenariuszy w czeskich filmach fantastycznonaukowych w latach 1918-1989] obronionej w 2015 roku na brneńskiej Janáčkovej akademie múzických umění również wyodrębnił trzy warianty filmowych podróży w czasie, w których:

1) bohater wędruje w jednym kierunku, tj. przenosi się do przyszłości, zachowując swój cielesny status podróżnika. Wykorzystuje do tego hibernację (Hibernatus, reż. A. Molinaro, Seksmisja, reż. J. Machulski) lub nadświetlną prędkość (Planeta małp, reż. J. Schaeffer);

2) bohater dostaje się do „innego czasu” traktowanego jako przestrzeń zamknięta. Przyczyną takiej podróży może być sen lub magia. Gdy wraca do swojego czasu, tylko on przeżywa wewnętrzną przemianę - świat się nie zmienia (Jankes na dworze króla Artura, reż. E.J. Flynn, Wehikuł czasu, reż. George Pal);

3) bohater wędruje w połączonych przestrzeniach czasu. W takiej koncepcji może dojść do zmiany teraźniejszości na skutek jego działań (Terminator, reż. J. Cameron). Czas może być potraktowany subiektywnie lub obiektywnie. Autor rozprawy, aby wyjaśnić tę różnicę, posłużył się następującym przykładem: „Wyobraźmy sobie, że w 10. minucie filmu bohater idzie na imprezę. Po jej zakończeniu wchodzi do laboratorium i w 20. minucie filmu podróżuje wehikułem czasu kilka godzin wstecz i znowu idzie na tę samą imprezę. Tam naturalnie

poznać odległą przyszłość, 3) pracują w instytucjach zajmujących się nadzorem nad czasem, 4) przenoszą się w czasie w wyniku przypadkowego zbiegu okoliczności lub awarii, patrz: K. Loska, Encyklopedia filmu science fiction, Kraków 2004, s. 58.

[6] Można wspomnieć także o innych popkulturowych obiegach. Motyw podróży w czasie przyniósł niezwykłe efekty w seriach komiksowych ukazujących na łamach czechosłowackich periodyków dla młodzieży. Jedną z ciekawszych jest Tvrz [Forteca] 24-planszowa historia narysowana przez Františka Kobíka, a napisana przez Václava Šorela, publikowana w latach 1980-1981 jako dodatek do kultowego dwutygodnika „ABC”. Bohater, czeski astronom Martin Hrubý, podczas podróży do swojego letniskowego domku przekracza barierę czasu, przenosząc się do 1534 roku do husyckiego zameczku Hlásenice, gdzie pomaga taboryckiej załodze w pokonaniu oblegających ją oddziałów przeciwników Kielicha, patrz: J. Ládek, R. Pavelka, Encyklopedie komiksu v Československu 1945-1989, Praha 2010, s. 154-157. Popularność komiksu była tak duża, że po kilkukrotnych wznowieniach Šorel opracował także jego wersję powieściową, patrz: V. Šorel, Tvrz, Praha 2016. Na łamach magazynu „ABC” ukazywały się także odcinki graficzne opowiadania autorstwa Lubomíra Hlavsy (rysunki) i Rudolfa Baudisa Stroj času, którego protagoniści odwiedzają między innymi renesansową Pragę i spotykają Golema, patrz: Velká kniha komiksu II, sestavil J. Buchal, Praha 2002, s. 293-324. Ponadto nie sposób pominąć jednego z najoryginalniejszych przykładów „kresleného” pokonywania czasu w ostatniej dekadzie, czyli projektu kolejnego klasyka czechosłowackiego komiksu Vlastislava Tomana, który od 1967 roku pisał scenariusze serii Stražcí dla wspomnianego wcześniej magazynu „ABC”. Początkowo były to historie pięcioosobowej drużyny pionierskiej, ale ostatnio ukazał się album z rysunkami Michala Kociána i Vladimíra Bicana z przygodami nowych bohaterów - uczniów praskiego gimnazjum wypraw kosmicznych. Piątka nastolatków w ramach praktyk odbywanych w Instytucie Poszukiwań Kosmicznych (IKS) wędruje w rozmaite rejony historii powszechnej i narodowej, patrz: V. Toman, M. Kocián, V. Bican, IKS. Strážci času, Velké Př́lepy 2018. 
spotka samego siebie. Są dwa filmowe rozwiązania - spotkanie różnych wersji bohatera można pokazać dopiero teraz w 20. minucie (percepcja subiektywna) lub już podczas pierwszej wizyty bohatera na imprezie w 10. minucie (percepcja obiektywna)?"[7].

W czeskiej fantastyce filmowej podróż w czasie, zdaniem Gotthardta, pojawiła się w pięciu filmach [8]: Człowiek pierwszego stulecia (1961) i Prátelé bermudského trojúhelníku (1987), które wykorzystywały wariant drugi, Panowie, zabiłem Einsteina (1969) i Jutro wstanę rano $i$ oparzę się herbata (1977) z ewidentną afirmacją wariantu trzeciego, w ujęciu subiektywnym oraz Něco je ve vzduchu (1980), w którym reżyser i scenarzysta zastosowali też figurę połączonych przestrzeni czasowych, ale w percepcji obiektywnej[9]. Autor tej niezwykle ciekawej analizy zapomniał o jednym filmie, niemieszczącym się w żadnej z opisanych kategorii, który miał być jedynie filmową lekcją przyrody, a okazał się nieśmiertelnym klasykiem gatunku.

Karel Zeman, realizując w połowie lat pięćdziesiątych Wyprawę w przeszłość [Cesta do pravěku], kierował się własną (nową) wrażliwością gatunkową[10]. „Rzeka czasu”, po której podróżują młodzi bohaterowie przez poszczególne epoki prahistorii, jest raczej metaforą edukacji i dociekliwości badawczej, dzięki którym poznajemy samych siebie, niż kluczem do niesamowitych przygód czy mrożących krew w żyłach spotkań z mamutami i dinozaurami[11], choć jedno i drugie da się po-

[7] P. Gotthardt, Skutečný stroj času. Scenáristické postupy v českých sci-fi filmech mezi lety 1918-1989. Disertační prace, Vedoucí práce: prof. Mgr. Jan Gogola, Divadelní fakulta Janáčkovej akademie múzických umění, Brno 2015, s. 83.

[8] Tytuły filmów, jeśli miały swoją polską premierę, podaję $\mathrm{w}$ takim brzmieniu, $\mathrm{w}$ jakim były rozpowszechniane w Polsce. W pozostałych przypadkach stosuję tytuły oryginalne.

[9] P. Gotthardt, op.cit., s. 82-84.

[10] Ladislav Tunys, wpływowy krytyk i niedoceniony kronikarz czechosłowackiej kinematografii, napisał: „Wysiłek oferowania widzom jakiegoś nowego, oryginalnego a jednocześnie zrozumiałego pomysłu najwcześniej dał efekt w Wyprawie w przeszłość. Do dzisiaj jednak nie wiem, do jakiego gatunku można ten film zaliczyć”, patrz: L. Tunys, Hvězdy, které nezhasnou aneb Jak jsem je poznal, Praha 2012, s. 389. [11] Taką opinię, jeszcze przed premierą Cesty do pravěku wyraził jeden z dziennikarzy „Rudého Práva”, pisząc: „Który z nas nie pragnął choć raz móc spojrzeć na dawno minione czasy, zobaczyć, jak wyglądał rozwój wszechświata, Ziemi i człowieka. Takie marzenia najczęściej snują młodzi chłopcy i młode dziewczęta. Dzisiejszy człowiek ma taką możliwość dzięki kamerze filmowej - która pozwala nam odtworzyć czasy najdawniejsze, dawno minione. I tak czterem pionierom spełnił się sen o poznaniu początków życia na Ziemi”, patrz: L. Hrudka, Cesta do pravěku (O natáčení nového loutkového filmu), „Rudé právo" 1953, nr 227, s. 2 (jeśli nie zostało zaznaczone inaczej, tłumaczenia z języka czeskiego i słowackiego są mojego autorstwa - MG). Podobnie intencje reżysera wyjaśniono w polskiej recenzji: „Film jest zasadniczo przeznaczony dla kilkunastoletniego odbiorcy, któremu realizatorzy dostarczają krótkiego przeglądu pradziejów powstawania życia na ziemi. Jest to wykład popularnonaukowy, przedstawiony w lekkiej formie, o treści niewymagającej żadnego przygotowania naukowego", patrz: Wyprawa w przeszłość, „Filmowy Serwis Prasowy” 1956, nr 11, s. 15. Szczególnie widoczne stało się to po latach, kiedy można było odnieść się do Cesty do pravěku w kontekście dalszej twórczości Zemana. Jak napisał jeden z najbardziej wnikliwych czeskich krytyków: „Nic w tym dziwnego, że film stał się znakomitym uzupełnieniem szkolnych podręczników. Zemanowi, co oczywiste, nie chodziło jedynie o wyreżyserowanie obrazu awanturniczego, 
godzić[12]. Film był sensacją międzynarodowych przeglądów, cieszył się uznaniem rodzimej publiczności (oficjalnie obejrzało go 2823323 widzów[13]), pokazywano go w niemal całej Europie[14], a dzisiaj nie tylko pozostaje w obiegu kinofilskim[15], ale także jest przedmiotem obszernych filmoznawczych analiz[16]. Zresztą drugie życie obrazowi Zemana, obok zremasterowanej w ramach projektu „Čistíme svĕt fantazie" [Porządkujemy świat fantazji] kopii, która w kwietniu 2019 roku trafiła do kin, zapewnił też zeszyt komiksowy według scenariusza Hostimila Schmiedla inspirowany filmowymi kadrami, a na dodatek sentymentalnie odnoszący się do celuloidowego pierwowzoru. Ostatnia plansza zawiera bowiem wizerunki odtwórców głównych ról zarówno jako nastolatków, jak i nobliwych seniorów[17]. Nie dało zapomnieć o Wyprawie w przeszłość także praskie Muzeum Karla Zemana, dla którego jako część programu „Kinohrani” grę planszową przygotowały Lena Mechtchanová i Anna Falzonová. W nieskrywany sposób do filmu Zemana nawiązał słynny słowacki dokumentalista Pavol Barabaš, który relację z najeżonej niebezpieczeństwami podróży po afrykańskiej rzece Omo zatytułował Omo - cesta do pravĕku[18].

Karel Zeman potrafił czarować niesamowitą konstrukcją swoich obrazów - ploskovą animacją, kombinowaną fakturą ujęć, estetyką niemal steampunkową, którą odkrył, śledząc XIX-wieczne ilustracje powieści Julesa Verne’a, co szczególnie uwidoczniło się w trzech następnych filmach będących adaptacjami książek francuskiego geniusza fantastyki: Vynález zkázy [Diabelski wynalazek, 1958], Ukradená $v z$ ducholod' [Skradziony balon, 1966] i Na kometě [Na komecie, 1970]. Czas, którzy przekraczają młodzi protagoniści Cesty do pravĕku, jest konstruktem, nad którym rządy sprawuje wyobraźnia i nieograniczona fantazja, ale oparte na solidnej wiedzy wynikającej z dociekliwości i pa-

bowiem chciał połączyć wiedzę z naturalną tęsknotą młodych ludzi do przygód i uczynił to tak doskonale i sugestywnie, że dzięki dziecięcej wyobraźni widz otrzymał naukowy wykład w formie filmowej fabuły", patrz: J. Hrbas, Karel Zeman. Pi̊vab chlepecké romantiky I, „Film a doba” 1974, nr 1, s. 23.

[12] Zresztą taką perspektywę sugerują pierwsze kadry filmu, inspirowane awanturniczymi powieściami Julesa Verne’a, konfrontujące marzenia Jirki - jednego $\mathrm{z}$ bohaterów $-\mathrm{z}$ wizytą całej czwórki w praskim $\mathrm{Mu}$ zeum Narodowym, gdzie podziwiają prehistoryczne kości i skamieliny.

[13] V. Březina, Lexikon českého filmu. 2000 filmů 1930-1996, Praha 1996, s. 54.

[14] Nie zawsze jednak zagraniczne recenzje miały afirmatywny charakter. Polski krytyk Zbigniew Pitera dostrzegł zarówno wady scenariusza, jak i niedoskonałości produkcyjne: „Co jednak najbardziej razi - to słaba technika animacji większości makietowych stworów. Okazuje się, że Karel Zeman, najznakomit- szy obok Jerzego Trnki filmowy kukiełkarz, zabrnął niepotrzebnie w tę syzyfową pracę, która nie dała oczekiwanego efektu ani artystycznego, ani technicznego, ani chyba poznawczego", patrz: Z. Pitera, Wyprawa w przeszłość, „Film” 1956, nr 50, s. 5 [15] J. Lukeš, Diagnózy času. Český a slovenský poválečný film (1945-2012), Praha 2013, s. 53.

[16] W roku 2019 ukazał się 6oo-stronicowy tom rozpraw pod redakcją Petra Kopala poświęcony rozmaitym aspektom filmu Karela Kachyňi Král Šumavy (1959). Z informacji zamieszczonej na trzeciej stronie okładki wynika, że kolejna publikacja będzie summą wiedzy na temat Cesty do pravěku i w 2020 roku przygotuje ją zespół pod kierownictwem Lukáša Skupy, patrz: Král Šumavy komunistický thriller, Praha 2019. [17] Karel Zeman, Cesta do pravěku, scénář Hostimil Schmiedl, Praha 2006.

[18] R. Pospiš, Dobrodružná cesta za miznúcim svetom, „film.sk” 2015, nr 5, s. 16. 
sji. Nie bez znaczenia jest fakt, że chłopcy są członkami młodzieżowej organizacji pionierskiej, a więc w dyskursie formacyjnym przyszłą elitą socjalistycznego społeczeństwa. Droga, jaką pokonują Jirka, Petr, Janda i Tonik, przypomina trasę muzealnej wycieczki pełną zgromadzonych artefaktów, zrekonstruowanych modeli zwierząt i skarbów paleontologicznych eksploracji. Widząc kręcącego trąbą mastodonta, jeden z pionierów krzyczy: „Mamut, opravdový mamut, kluci. Ten. Takový kolos” [Chłopaki, prawdziwy mamut, jaki wielki] i dodaje „Haló, pane mamute. Jsme tady dobre, v pravěku?" [Halo, panie mamucie, Dobrze trafiliśmy, jesteśmy w pradziejach?] - wydaje się, że okrzyk ten nie wyraża przerażenia i grozy, ale podziw dla mogącego poznać tajemnice swego pochodzenia człowieka[19]. Te same emocje będą towarzyszyły bohaterom Parku jurajskiego Stevena Spielberga po ponad czterdziestu latach[20]. Zresztą naukowy aspekt bardzo zajmował Zemana. Jego córki po latach wspominały:

Ojciec bardzo długo oswajał się z myślą, by ożywić na ekranie prehistoryczną przyrodę i żyjące wtedy stworzenia. Kiedy zaczął kręcić film w latach pięćdziesiątych, niewiele wiedzieliśmy o dziejach Ziemi przed pojawieniem się człowieka. Jako dzieci znaliśmy jedynie wizerunki niektórych paleohistorycznych zwierząt dzięki ilustracjom Zdeňka Buriana[21]. Burian swymi doskonałymi obrazkami inkrustował także książki naszego sławnego paleontologa prof. Josefa Augusty. Aby film mógł powstać, ojciec musiał jak najszybciej przestudiować sporo naukowej literatury i poprosić o konsultacje ekspertów, takich jak wspomniany prof. Augusta. Z jego osobistym udziałem i wielkim poświęceniem zrekonstruowane zostały potwory z pradziejów[22].

[19] Warto przytoczyć opinię, jaką na temat dydaktycznych walorów filmu Zemana, w kontekście czechosłowackiej produkcji dla dzieci i młodzieży, wyraziła jedna z publicystek miesięcznika „Film a doba”: „Fabuła jest pomyślana jak subiektywna lektura obrazkowego podręcznika do przyrody (czterech młodzianów podczas nauki wyobraża sobie pobyt na Ziemi w czterech epokach geologicznych). Żródłem przygód i doznań nie są pokonywane niebezpieczeństwa, ale poznawanie prehistorycznych zwierząt i dziwów natury. Chodzi tu o moment permanentnego zaskakiwania, bowiem emocje są napędzane napięciem między współczesnością, którą reprezentuje obecność czterech młodych bohaterów i ich komentarze, a przeszłością, która wypełnia świat otaczający chłopców", patrz: M. Benešová, Tematické proměny ve filmech pro dëti, „Film a doba” 1970, nr 6, s. 323.

[20] W czeskiej literaturze popularnonaukowej pojawiły się nawet sugestie o wpływie estetyki Zemana na Spielbergowskie wizje spotkania $\mathrm{z}$ dinozaurami: „Przedmiotem ciekawego kinematograficznego sporu jest to czy Spielberg widział Wyprawę w przeszłość przed lub w trakcie kręcenia Parku jurajskiego. W jednym $\mathrm{z}$ wywiadów on sam stwierdzil, że zna ten filmu i bardzo mu się podobał, chociaż w innej rozmowie zaprzeczył, iż się nim inspirował, patrz: O. Slanina, Slavná česká filmová klasika, Praha 2013, s. 34. [21] Zdeňek Burian, malarz i ilustrator książkowy, specjalizował się głównie w rekonstrukcjach paleontologicznych. Współpracował nie tylko z Josefem Augustą, ale także profesorem Uniwersytetu Karola Zdeňkiem Špinarem. Jego prace można podziwiać na co dzień w Muzeum Zdeňka Buriana w Štramberku na Morawach, ale wiosną 2013 roku w Obecním domĕ w Pradze zorganizowana została wystawa jego ilustracji do książek Jacka Londona, Karola Maya, Artura Ransoma, Jules’a Verne’a i czeskiego podróżnika Enrique Stanko Vráza, patrz: J. Sluka (red.), Zdeňek Burian. Na vlnĕ dobrodružství. Katalog k vystavĕ Zdeňka Buriana v Obecním domě v Praze 12 února 2013 - 19 brezna 2013, Praha 2013, s. 6-7.

[22] L. Zemanová, L. Zemanová Spaleny, Karel Zeman a jeho kouzelný svĕt, Brno 2015, s. 74. 
Nakręcenie takiego obrazu jak Cesta do pravěku było w połowie lat pięćdziesiątych nie lada wyzwaniem produkcyjnym. Film kombinowany z udziałem jedynie czterech dziecięcych aktorów, kilkudziesięcioma modelami mastodontów, dinozaurów, brontozaurów czy bliższych nam antylop i krokodyli z wyrafinowaną estetyką animacyjną właściwą kinu eksperymentalnemu nie gościł zbyt często na ekranach[23]. Problemy realizacyjne generowała też mnogość ekspozycji zlokalizowanych zarówno na Słowacji, gdzie, wykorzystując urodę Wagu - dopływu Dunaju w okolicach miasteczek Šala i Galanta - kręcono sekwencje przybrzeżne, jak i w Czechach w Strmilovie koło Jindřichova Hradce czy nawet na bałtyckiej wyspie Rugia, która dzięki współpracy ze wschodnioniemiecką DEFA posłużyła jako sceneria ostatnich ujęć. Jednak efekt zależał od studyjnej inscenizacji:

W Hostivařskim atelier kończy się realizacja filmowych ujęć z udziałem aktorów. Otwórzcie pancerne drzwi, a zobaczycie zadziwiającą przestrzeń. Widok świata sprzed setek tysięcy lat jest oszałamiający. Ogromna, dawno wymarła roślinność, która tworzy dziki, ale porywający pralas, i otaczające całość ekspozycji kopuły wulkanów są nad wyraz sugestywne. Studio jest zalane wodą, kamera umieszona została na tratwie, a czwórka chłopców czeka na jej włączenie. Reżyser po raz kolejny każdemu z nich tłumaczy jak ma się poruszać i co ma powiedzieć. Potem jeszcze spojrzenie na skałkę, gdzie ma być kręcone ujęcie, tam gdzie woda jeszcze nie zmyła pnączy i jazda... Mali aktorzy robią parę kroków i wypowiadają swoje kwestie. Reżyser nie jest zadowolony. Trzeba scenę kręcić jeszcze raz[24].

Niebagatelną funkcję pełniła także muzyka skomponowana przez Emila Františka Buriana, dla którego była to dwudziesta trzecia, a zarazem ostatnia przygoda $\mathrm{z}$ filmem. „Udział w pracy nad tą produkcją był świadectwem przekonania o wartości filmów przeznaczonych dla młodzieży, co zresztą udowodnił już wcześniej. Jednak ważne wydarzenia w naszej kulturze, kłopoty $\mathrm{z}$ frekwencją we własnym teatrze, oraz nagłe symptomy choroby sprawiły, że 15 sierpnia zmarł, a instrumentację ścieżki dźwiękowej Cesty do pravěku dokończył Vlastimil Pinkas”[25] - pisano po latach na łamach miesięcznika „Film a doba”.

Podróże w czasie nie przestały interesować czeskich filmowców. Znamiennym przykładem wykorzystania tego motywu może być udana próba wpisania go w gatunkowy paradygmat komedii, a właściwie najbardziej nadwełtawskiego jej wariantu - komedii zwariowanej (bláznivá komedie). W roku 1969 Oldřich Lipský podpisał się pod filmem Panowie, zabiłem Einsteina [Zabil jsem Einsteina, pánové...]. Podstawą literacką był skrypt Josefa Nesvadby, jednego z prekursorów

[23] M. Benešová, Zápas o tvar. K životnímu jubileu narodního umĕlce Karla Zemana, „Film a doba” 1980, nr 12, s. 666.
[24] Žka [Jiří Nožka], Nahlédli jsme do atelieru, „Svĕt v obrazech" 1954, nr 12, s. 19.

[25] L. Linhart, E.F. Burian \& film, „Film a doba” 1970, nr 2, s. 102. 
powojennej czeskiej fantastyki literackiej. Nesvadba był z wykształcenia psychiatrą, ale, władając świetnie językiem angielskim, dość wcześnie zajął się przekładami i pisaniem własnych sztuk teatralnych. W 1958 roku wydał zbiór opowiadań Tarzanova smrt [Śmierć Tarzana], który krytyka porównywała z międzywojennymi osiągnięciami Karela Čapka, a historycy literatury pisali, że: „Josef Nesvadba swoimi zbiorami opowiadań publikowanymi od późnych lat pięćdziesiątych kształtował intelektualny nurt czeskiej prozy science fiction. Używał zwykłych motywów gatunkowych do konstruowania urzekających historii, ale wprowadzał do nich różne paradoksy historyczne oraz współczesne niepokoje etyczne, filozoficzne i psychologiczne" [26].

Tytułowy utwór oraz inne opowiadanie Blbec z Xeenemünde [Gamoń z Xeenemünde] z późniejszej antologii Einsteinův mozek [Mózg Einsteina] zostały przeniesione na ekran w 1962 roku przez Jaroslava Balíka i od lutego 1963 roku pokazywane były jako jednolita propozycja repertuarowa w kinach.

Oldřich Lipský był jednym z najbardziej rozpoznawalnych przedstawicieli czeskiej komedii, dzięki zrealizowanemu w 1964 roku na podstawie powieści Jiříego Brdečki Lemoniadowemu Joe [Limonádový Joe] i... swojemu bratu Lubomírowi, aktorowi znanemu zarówno ze sceny, jak i ekranu, którego dezynwoltura przyczyniła się do sukcesów wspólnych filmów[27]. Z fantastyką filmową po raz pierwszy zmierzył się na początku lat sześćdziesiątych, realizując futureskę Człowiek $z$ pierwszego stulecia [Muž z prvního století, 1961], w której zaprezentował postapokaliptyczną wizję społeczeństwa konsumpcyjnego z XX wieku skonfrontowaną z obrazem idealnej wspólnoty z przyszłości[28]. Od tej produkcji z początku dekady (pierwotnie miała nosić tytuł Zavinil to Einstein) prosta droga prowadziła do kolejnego dzieła, w którego agendzie czas nie ograniczał wyobraźni scenarzystów. Panowie, zabiłem Einsteina, powstał na przełomie ważnych wydarzeń zdławienia niepodległościowej rebelii, którą w uproszczeniu nazywa się Praską Wiosną, a normalizacją, którą bezpośrednio poprzedziła

[26] P. Janáček, Vědecká fantastika, [w:] Dějiny české literatury 1945-1989, III. 1958-1969, red. P. Janáček, Praha 2008, s. 512.

[27] Lubomír był o rok starszy od Oldřicha, ale przeżył go o niemal 30 lat. Rozpoczął swą karierę w wojennym dramacie Františka Čápa $V$ horach duni (1946), a ostatnią rolę zagrał w czwartej części Kameňáka Zdeňka Troški (2013). Znany był z roli porucznika Borůvki, w którego wcielił się w nowelowym filmie nakręconym na podstawie opowiadań Josefa Škvoreckýego Zbrodnia w żeńskiej szkole [Zločin v dívči škole, 1966] w reż. Iva Nováka, Ladislava Rychmana i Jiř́ego Menzla. Zagrał w większości filmów swojego brata, takich jak: Slepice a kostelník (1950), Dziś wieczór gramy [Cirkus bude!, 1954], Vzorný kinematograf Haška Jaroslava (1955), Hvězda jede na jih (1958), Człowiek z pierwszego stulecia [Muž z prvního století, 1961], Panowie, zabilem Einsteina [Zabil jsem Einsteina, pánové..., 1969], Trup w każdej szafie [Čtyři vraždy stačí, drahoušku, 1970], Slaměný klobouk (1971), Sześć niedźwiedzi i klaun Cibulka [Šest medvědů s Cibulkou, 1972], Tři chlapi na cestách (1973), Horoskop szczęścia [Jáchyme, hod'ho do stroje!, 1974], Cyrk w cyrku [Cirkus v cirkuse, 1975], Niech żyją duchy! [At'žijí duchové!, 1977], Tři veteráni (1983) i Velká filmová loupež (1986). O wzajemnych artystycznych i rodzinnych losach braci Lipskich patrz: K. Ulík. Lubomír Lipský a jeho bratr Oldřich, Praha 2011.

[28] Z. Hudec, A. Novobilská, Filmová komedie, [w:] Panorama českého filmu, (sest.) L. Ptáček, Olomouc 200o, s. 287. 
inwazja wojsk Układu Warszawskiego w sierpniu 1968 roku. Jan Kliment - jeden czołowych inkwizytorów posierpniowej kultury, piszący między innymi na łamach głównego narzędzia normalizacyjnej opresji, dziennika KSČ (Komunistycznej Partii Czechosłowacji) „Rudé právo” jeszcze na początku 1970 roku nie dostrzegł w filmie jakichkolwiek politycznych konotacji:

To film przede wszystkim gatunkowy. Komedia z zacięciem fantastycznym nakręcona jedynie po to, żeby rozbawiać i śmieszyć. I robi to ze smakiem, większość scen ma świetne tempo, a na ekranie widzimy znane twarze popularnych aktorów. Jednak jakiejś głębszej myśli widzowie się nie dopatrzą, więc i ja takiej nie szukam, bowiem też jestem widzem jak i oni[29].

Kliment posłużył się również filmem Lipskiego w omówieniu pierwszego "poinwazyjnego" karlowarskiego festiwalu, ale w tym przypadku czytelnicy „Rudého práva” musieli zauważyć polityczne odniesienia. Zabiłem Einsteina, panowie był reprezentantem czechosłowackiej kinematografii w konkursie głównym, choć miejsce to wcześniej było zarezerwowane dla filmu Jaromíra Jireša Valeria i tydzień cudów [Valerie a týden divi̊, 1970], poetyckiej, drapieżnej, nawiązującej do poetyki grozy ballady nakręconej na podstawie opowiadania Vítězslava Nezvala. Kliment tak uzasadnił ten wybór:

Kilka dni temu obejrzałem najnowszy filmu Jireša Waleria i tydzień cudów. Pomijając niewątpliwe walory pracy operatorskiej Čuř́ka[ ${ }^{30}$ ], o samym filmie nie mogę powiedzieć nic pozytywnego. Jest on prawdziwą męką dla widzów i najlepiej pokazywać go w ograniczonej dystrybucji. Nic więc dziwnego, że czeską kinematografię będzie reprezentowała komedia sf Oldřicha Lipskiego Panowie, zabitem Einsteina, która przynajmniej w naszych kinach cieszy się popularnością. Nie widzę powodów, dla których tzw. filmy dla widzów nie mogłyby być pokazywane na festiwalach[31].

Oczywiście, gatunkowy charakter przedsięwzięcia nie budził wątpliwości. Wspomniane w recenzji kreacje aktorskie Jiříego Sováka, Ludomíra Lipskiego, Miloša Kopeckýgo, Josefa Kemra czy Jany Brejchovéj wzmacniały ten typ recepcji[32]. Większość odtwórców kojarzyła się z komediowym kontekstem i nie zamierzała tego w radykalny sposób zmieniać. Autor popularnego leksykonu Jiř́ Levý w połowie lat

[29] J. Kliment, Pro dobrou náladu, „Rudé právo” $1970, \mathrm{nr} 48$, s. 5 .

[30] Jan Čuř́k (1924-1996) był wybitnym czeskim operatorem, który zadebiutował w 1955 roku filmem Tanková brigáda (reż. I. Toman). Współpracował $\mathrm{z}$ wieloma twórcami, ale najwybitniejsze dzieła stworzył w tandemach z J. Jirešem i K. Kachyňą.

[31] J. Kliment, Polský di̊kaz v Karlových Varech, „Rudé právo" 1970, nr 269, s. 4.

[32] Po latach Zdeňek Svěrák, który wystąpił w kilku jego filmach, tak scharakteryzował O. Lipskiego: „Gdybyście go spotkali na ulicy, nawet byście się nie zorientowali, że jest reżyserem filmowym. Ten łysawy facet w okularach chodził z wytartą teczką i nie wiadomo czym wypchanymi kieszeniami, a jeśli coś z nich wystawało, to kartka z rozrysowanym pomysłem nowego filmu. Kiedy stawał za kamerę, już myślał o następnym projekcie, żeby nie tracić swego cennego czasu. Był specjalistą od komedii i naprawdę potrafił je kręcić, a przede wszystkim umiał wybrać właściwych aktorów. Spróbujcie sobie wyobrazić inne kreacje $w$ jego filmach. To niemożliwe, a ponadto kochał aktorów i to z wzajemnością", patrz: M. Černík, 35 českých filmowych režisérů očima Zdeňka Svěráka, Jiřího Suchého, Květy Fialové, Radka Brzobohatého a v karykaturach Michala Černíka, Praha 2010, s. 63. 
osiemdziesiątych, krótko przed przedwczesną śmiercią reżysera, miał do powiedzenia jedynie: „Filmy narodowego artysty Oldřicha Lipskiego pełniły bardzo ważną społecznie funkcję - dawały widzom zdrowy i bezpretensjonalny optymizm. Dlatego były wyświetlane z nadzwyczajnym powodzeniem nie tylko w Czechosłowacji. Należały też do najbardziej eksportowych dokonań naszej kinematografii”[33].

Przy bardzo ostrożnej próbie traktowania Panowie, zabiłem Einsteina, jak to nazwał Kliment, jedynie jako „diváckého filmu” [filmu dla widzów], nie sposób nie zauważyć, że wpisywał się on w pewnego rodzaju konwencję charakterystyczną dla schyłku ponowofalowego porządku na Barrandovie. Wyznaczała ją stylistyka parodii gatunkowych, od westernów poczynając, poprzez kino gangsterskie, na fantastyce kończąc[34]. Z jednej strony taki wariant repertuarowej produkcji był propozycją familijną, gromadzącą widownię niezainteresowaną kontestacyjnym podtekstem[35], ale z drugiej dawał możliwość ukrywania między dialogami, konotacjami scenograficznymi lub nawet odniesieniami aktorskimi treści, które nie mogły być kontrolowane przez coraz bardziej inkwizycyjny aparat normalizacyjnego państwa.

Treść opowiadania Nesvadby i akcja filmu Lipskiego oparte są na modelu paradoksu czasowego i... specyficznym środkowoeuropejskim poczuciu humoru. W niedalekiej przyszłości, na skutek terrorystycznej działalności grupy „fanatycznych fizyków” i użycia przez nich bomby G, kobietom zaczęły rosnąć brody. Niczym futurystyczne Lizystraty wypowiadają posłuszeństwo mężczyznom, nie usuwając swojego owłosienia. Międzynarodowe władze (tu jest mowa o Organizacji Narodów Zjednoczonych) postanawiają wykorzystać prototyp wehikułu czasu, aby wysłać w przeszłość do Pragi początków XX wieku misję naukowców: prof. Davida Moore (Jiří Sovák), prof. Franka Pecha (Lubomír Lipski) i dr Gwen Williams (Jana Brejchová). Ich zadaniem jest odnalezienie przebywającego w późniejszej stolicy Czech Alberta Einsteina (Petr Čepek) i uśmiercenie go. Wyprawa kończy się kompletną klapą - Einstein nie dość, że uniknie zamachu, to na skutek zakłócenia kontinuum czasowego dr Pech rozpłynie się w powietrzu - nigdy się nie narodzi, ponieważ działania trójki spiskowców z przyszłości spowodują śmierć jego ojca, który w 1911 roku był nastoletnim urwisem. Po powrocie do lat dziewięćdziesiątych XX wieku prof. Moore postanawia naprawić błąd i jeszcze raz użyć wehikułu czasu, ale jego zamierzenia krzyżują spiskowcy, którym przewodzi prof. Robert Grant (Radoslav Brzobohatý). Mają oni własne plany związane z manipulowaniem czwartym wymiarem. W efekcie niemal slapstickowych zwrotów akcji Albert Einstein przestaje interesować się fizyką, która zaczyna egzystować na peryferiach nauki i rozwija swój talent muzyczny, stając się wirtuozem

[33] J. Levý, Českoslovenští filmoví režiséři sedmdesátých let, Praha 1983, s. 49.

[34] P. Szczepanik, Továrna Barrandov. Svět filmařu a politická moc 1945-1970, Praha 2016, s. 344.
[35] P. Kopal, Normalizace - deformace - dekadence. Několik drobnych poznámek o filmovém a televizním Monstru (1970-1990), [w:] Film a déjiny 4. Normaliza$c e$, red. P. Kopal (ed.), Praha 2014, s. 414. 
skrzypiec. Lipski był zatem zainteresowany snuciem historii alternatywnych, nakłuwaniem jej wariantów i w konsekwencji pokazywaniem pewnej bezradności narracyjnej, na jaką cierpiała fantastyka w latach siedemdziesiątych. Sam powiedział, komentując dość niesamowity wątek pobytu Einsteina jako wykładowcy niemieckiego uniwersytetu w Pradze w roku 1911:

Wyszliśmy z założenia, że science fiction oferuje nam niesamowitą możliwość powrotu do przeszłości. Podkreślam to dlatego, że wielu ludzi mylnie sądzi, iż ten gatunek zajmuje się jedynie wyprawami w kosmos lub opowiadaniem o przyszłości. A co to za fikcja, skoro o lotach w kosmos już kręci się dokumenty. Gdy chodzi o wehikuł czasu, to nie przejmowała nas specjalnie logika technologiczna czy jej naukowe podstawy. Widz powinien zaakceptować jej istnienie, bo inaczej nie pogodziłby się z faktem, że pięćdziesięcioletni syn spotyka dziewięcioletniego ojca. Musi po prostu na ten film patrzeć tak, jak się patrzy na ekranowe bajki[36].

Czołówka filmu Jutro wstanę rano i oparze się herbata [Zitra vstanu a opařím se čajemu, 1977] uświadamia, że konwencja zaproponowana na przełomie dekad w futurystycznej komedii Panowie, zabiłem Einsteina miała się dobrze i pozwalała na kolejne ekranowe eksperymenty. Gwarantami byli ci sami scenarzyści Nesvadba i Macourek, ale też nowy reżyser. Oldřicha Lipskiego, który w normalizacyjnym kinie czechosłowackim nie zrezygnował z groteski, ale ubrał ją w bardziej realistyczne szaty, godnie zastąpił Jindřich Polák[37] - twórca inspirowanej prozą Stanisława Lema kosmicznej opowieści z 1963 roku Ikaria $X B-1$ [Ikarie XB-1]. Nie tylko z uwagi na szczególny kultowy status, jakim cieszy się do tej pory ten obraz[38], J. Polák jest postacią dla czechosłowackiej fantastyki dość istotną. W latach 1969-1970 rozpoczął produkcją siedmiu obrazów pierwszą serię ekranowych przygód magicznego włóczykija Pana Tau. Powstała ona w koprodukcji z telewizją zachodnioniemiecką, kontynuowano ją przez niemal całą dekadę, a pomysłodawcą był znakomity pisarz i scenarzysta Ota Hofman, który miał na koncie tak wyrafinowane projekty narracyjne, jak scenariusze do filmów Juraja Herza (Panna a netvor, 1978) i Karela Kachyňi (Malá

[36] J. Vagaday, Zabil jsem Einsteina, panové aneb nová science-fiction pánů Nasvadby, Macourka, Lipskégo, „Kino” 1969, nr 21, s. 9.

[37] Biograf Vladimíra Menšíka, którego można było zobaczyć w roli hitlerowca Rolfa Krausa, potraktował tę realizację jako zamierzone qui pro quo: „Jak wiadomo w dziedzinie twórczości dla dzieci liczyły się w naszej kinematografii dwie pary autorskie Václav Vorliček - Miloš Macourek i Jindřich Polak - Ota Hofman. W 1977 roku zdarzyło się, że te dwie pary się przemieszały: Macourek tym razem wspólnie z Polákiem stworzył komedię Jutro wstanę rano i opa- rzę się herbatą. Pomysłodawcą fabuły był ulubiony pisarz sf Josef Nesvadba", patrz: L. Holčák, Vladimír Menšík a jeho filmy, Ostrava 2015, s. 330.

[38] W 1996 roku powstał między innymi z inicjatywy Ondřeja Neffa, Pavla Kosatika i Ivana Adamoviča, magazyn sf „Ikarie XB-2”, będący kontynuacją ukazującego się w latach 1986-1989 fanzinu „Ikarie XB-1". Jego twórcy nie kryli, iż nazwa nawiązuje do filmu J. Poláka. Od 2010 pismo ukazuje się pod tytułem „XB-1”, a jego redaktorem jest słowacki pisarz i tłumacz literatury fantastycznej Vlado Ríša. 
mořská víla, 1976) [39]. „Fantastyczna” współpraca Hofmana z Polákiem trwała jeszcze długo - w latach osiemdziesiątych spod ich ręki wyszedł pełnometrażowy dyptyk Lucie, postrach ulicy [Lucie, postrach ulice, 1983] - Znowu ta Lucie [... a zase ta Lucie!, 1984], a przede wszystkim niezwykle popularny w całym obozie komunistycznym serial Goście [Návštěvníci, 1983], który był kolejnym przykładem kooperacji autorskiej spółki z zachodnioniemieckim przemysłem filmowym[40].

Jutro wstanę rano i oparze się herbata jest filmem, który będąc emanacją normalizacyjnej zwariowanej komedii z fantastycznym wątkiem, tworzy jednocześnie pole dla ciekawych intertekstualnych strategii interpretacyjnych[41]. Treść, co oczywiste, bo oparto ją na tej samej obsesji Nesvadby, przypomina omówioną wcześniej komedię Panowie, zabiłem Einsteina, choć zdecydowanie bardziej wyakcentowany został aspekt polityczny. Grupa pogrobowców Hitlera, Klaus Abard (Jiří Sovák), Rolf Kraus (Vladimír Menšík) i inż. Bauer (Vlastimil Brodský), chce wykorzystać najnowszy wynalazek (oczywiście będący konsekwencją rozwoju socjalistycznej myśli technologicznej) - rakiety do podróży w czasie, używane do wycieczek komercyjnych dla bogatych dziwaków[42]. W tym celu byli esesmani przekupują jednego z pilotów takich urządzeń Karela Bureša (Petr Kostka[43]), który zgadza się dostarczyć Hitlerowi wykradzioną z waszyngtońskiego muzeum bombę wodorową. Plany nazistów, kilkakrotnie zresztą wędrujących do przeszłości, krzyżuje dobry bliźniak pilota - Jan i świat zostaje uratowany, przed zgubnym odwróceniem skutków II wojny światowej.

O dziwo, recenzje, jakie ukazały się po premierze, wcale nie były entuzjastyczne. Podkreślały gatunkowe pomieszanie materii, nadmiar zwrotów akcji - za co piszący na łamach słowackiego magazynu „Film

[39] Więcej o filmowych dokonaniach O. Hofmana, patrz: O. Slanina, Poutník svĕtem fatazie, Praha 2018, s. 78-193.

[40] W popularnym przewodniku po czechosłowackich serialach telewizyjnych umieszczono ciekawą konstatację: „Znakomity serial adresowany do dzieci, okazał się propozycją rodzinną. Autorska spółka Hofman i Polák zaoferowała scenariusz pełen ciekawych pomysłów i technicznych atrakcji. Rzeczywistość w naturalny sposób połączyła się z fantazją, co było widać tak w dialogach jak i w poszczególnych scenach", patrz: J. Moc, Seriály od A do Z. Lexikon českých serialü, Praha 2009, s. 138.

[41] Na temat ukrytych znaczeń w filmie Jindřicha Polaká pisałem kilka lat temu w szkicu poświęconym temu zagadnieniu. Poza oczywistym motywem zagrożenia atomowego, którego w retoryce globalnego konfliktu nader często używano, w obrazie można także dopatrzeć się tropów kulturowych jak wątek doppelgängera - złego bliźniaka, który może być w tym kontekście rozpatrywany jako ideologiczne rozbicie czeskich postaw narodowych, patrz: $\mathrm{M}$. Gu- zek, Jak kino czechosłowackie detonowało bombe atomowa, czyli o czym opowiada film Iindricha Poláka Jutro wstanę rano i oparzę się herbata (1977), „Przegląd Humanistyczny" 2017, nr 1, s. 95-96.

[42] W dialogach pojawiają się nawet ulubione trasy takich turystycznych eksploracji czasoprzestrzeni, między innymi do Egiptu w czasach budowniczych piramid, na pole bitwy pod Sławkowem (Austerlitz) W 1805 roku oraz do miejsc kojarzonych ze zwycięstwem nad hitlerowskimi Niemcami. W tych ostatnich gustują głównie bogaci Amerykanie.

[43] W tym filmie Kostka pokazał swoje komediowe predyspozycje, które wykorzystał w jeszcze jednym obrazie Szpinak czyni cuda [Což takhle dát si špenát] w reż. Václava Vorlíčká. W jego bogatej karierze aktorskiej dominowały role twardych mężczyzn, w których obsadzali go zarówno twórcy pełnometrażowych fabuł (Spanilá jizda, Zločin v dívčí škole), jak i producenci telewizyjnych seriali (Inženýrská odysea, Sanitka), patrz: R. Rohál, Krasavci filmového nebe, Praha 2009, s. 65. 
a divadlo" Peter Sever obciążył Josefa Nesvadbę[44], choć inne omówienia, jak napisane przez Jana Klimenta, mimo podobnych zastrzeżeń, były dla twórców bardziej łaskawe. Kliment musiał jednak wtrącić swoje normalizacyjne trzy grosze: „Pozostawmy te wątpliwości, bo warto zauważyć, że nowy film ma też humanistyczne przesłanie i swoją ideologią ostro kontrastuje z takimi projektami filmowej fantastyki jak tegoroczny amerykański reprezentant na moskiewskim festiwalu, o którym już pisałem na łamach „Rudého práva”. Nasz film prezentuje się dużo lepiej i to zarówno technologicznie, jak i pod względem fabuły”[45].

Jindřich Polák nazwał swoje dzieło „tragikomedią fantastycznonaukową" [46]. Tragikomiczny był oczywiście kontekst narracyjny - sposób opowiadania o wojnie w konwencji farsy, w latach siedemdziesiątych już oswojony nie tylko w kinie europejskim. Fantastycznonaukowy konterfekt nawiązywał do literackiej idée fixe autora pierwowzoru literackiego Nesvadby, którą scenarzysta Macourek ubrał w taką formułę, w której roiło się od czasowych paradoksów, jak choćby spotkanie samego siebie w przeszłości. Jedna rzecz łączy te dwa porządki - spotkanie ze Złem, czyli kolejny, tym razem fantastyczny, wizerunek Adolfa Hitlera. Oddajmy głos reżyserowi: „Fascynowała mnie możliwość związana z osobą Hitlera, której chyba wcześniej w kinematografii nikt nie potrafił wykorzystać - skonfrontowanie go ze skutkami jego ludobójczej polityki. Widzieliśmy na ekranie filmowym rozmaite jego wcielenia, ale jeszcze żaden $\mathrm{z}$ reżyserów nie postawił go twarzą w twarz z historyczną prawdą późniejszych lat. Koncepcja naszego film nam to umożliwiała, co prawda w postaci prześmiewczej, którą osobiście uważam, że jeden najskuteczniejszych sposobów" [47].

W latach osiemdziesiątych pojawiły się na czechosłowackich ekranach jeszcze dwa filmy z motywem podróży w czasie - na początku dekady Něco je ve vzduchu (reż. Ludvík Ráža, 1980) i w drugiej jej połowie złożona z trzech nowel fabuła Př́telé Bermudského trojúhelníku (reż. Petr Šícha, Jan Prokop, Václav Křístek). Były to przedsięwzięcia na tyle nieudane - w sumie obejrzało je w kinach nieco mniej niż 200000 widzów, że dzisiaj niemal nikt o nich nie pamięta[48]. Na przełomie

[44] Napisał on: „Josef Nesvadba nie jest nowicjuszem w krainie filmowej fantazji, wydaje się jednak, że tym razem nadto zagmatwał intrygę i nawet inteligentny widz ma co robić, aby szczególnie w drugiej części filmu zorientować się, kto jest kim. Nie protestowałbym przeciwko takim komplikacjom, gdyby służyły podstawowemu zadaniu filmu - rozśmieszaniu. Wydaje się jednak, że i scenariusz, i reżyseria nie mogły z tego pomysłu wycisnąć więcej. [...] A szkoda”, patrz: P. Sever, Trochu prekomplikované, „Film a divadlo” 1977, nr 17, s. 13.
[45] J. Kliment, Nová československá filmová komedie. Čaj ne zrovna nejsilnějši $i$, „Rudé právo” 1977, nr 200, s. 5 .

[46] A. Joneš, Vo fantastickej rakete. O filme Jindřicha Poláka Zitra vstanu a opařim sa čajem, „Film a divadlo" 1976 , nr 17, s. 16.

[47] E. Jelinková, Vím, že se zitra opařím čajem, „Kino” 1976, nr 20, s. 6.

[48] V. Březina, op.cit., s. 251, 333. 
stuleci czeska fantastyka naukowa zeszła niemal do produkcyjnego podziemia. Najczęściej reprezentują ją niskonakładowe projekty nawiązujące do formuły fałszywych dokumentów, jak Choking hazard (2004) Marka Dobeša czy Vaterland - lovecký deník (2004) Davida Jařaba lub etiudy studenckie w rodzaju Malého svĕta (2004) Vita Karasa i Jsem brána (2017) Robina Kašpaříka, pokazywane głównie na festiwalach i przeglądach organizowanych przez fandom. Scenariusze, nawet najbardziej interesujące, spotykają się z całkowitą obojętnością branżowych liderów, czego przykładem są losy niezrealizowanych skryptów, takich jak Adolf Hitler nemá rád disco czy Hercí, za które scenarzysta Václav Holanec został wyróżniony w konkursie o nagrodę Sazky[49]. Tematycznie preferowany jest taki rodzaj fantastyki, który ukazuje świat magiczny, wpisany w narodowe doświadczenie. Stąd gdzieś na obrzeżach głównego nurtu pojawiają się wątki golemiczne (animowany Golem, 1996, reż. Jiří Barta[50], Maharal - Tajemství talismanu, 2005, reż. Pavel Jandourek[51]) lub demonologiczne (Kozí príbeh - Pověsti stare Prahy Jana Tománka, 2008[52]), ale o podróżach w czasie zapomniano i nic nie wskazuje, by miało się to zmienić. Ivan Adamovič, informując o pomyśle nakręcenia przez Martina Krejčíego filmu Suplent z Ivanem Trojanem w roli głównej, napisał: ,jest bliski realizacji, ale daleki od pełnokrwistej fantastyki naukowej”[53]. Można to zdanie, rozciągając na całą postczechosłowacką kulturę filmową, potraktować jak diagnozę.

[49] Herci to opublikowany w 2012 roku debiut literacki Václava Holanca. Książka składa się z trzech rozbudowanych nowel, w których pojawia się specyficzne potraktowanie czasu jako materii narracyjnej. Tym razem nie są to jednak temporalne wojaże, lecz alternatywne wizje historii. Punktem wyjścia jest rok 1956, ale tylko pierwsza część odwołuje się do rzeczywistych wydarzeń, druga pokazuje świat, w którym Niemcy pierwsi użyli bomby atomowej, na skutek czego zawarły traktat pokojowy ze Stanami Zjednoczonymi i zapewniły sobie dominację nad całą Europą. W trzecim segmencie mamy do czynienia z sytuacją, w której czeskim komunistom nie powiódł się lutowy pucz 1948 roku, a ich partia została zdelegalizowana. Krytyka zalicza ten utwór do nurtu „niegatunkowej literatury” opisującej narodowe traumy na pograniczu realizmu i fantastyki. Zwolennicy takiego poglądu ukuli nawet termin „fantastika z tohoto světa" [fantastyka z tego świata]. Oprócz powieści Holanca reprezentują ją między innymi takie książki jak: Klokat dehet (2006) Jáchyma Topola i Všechno je jenom dvakrát (2016) Michala Přibáňa, patrz: T. Dědinová, J. Křeček, Jak je na tom současná česká fantastika?. Hledání hranic žánru a čtenáré, „Host. Měsíčník pro literaturu a čtenáře” 2018, nr 4, s. $40-41$.
[50] Jiří Barta zabiegał o realizację filmu animowanego, opartego na motywach powieści Gustava Meyrinka Golem prawie dwadzieścia lat, ale problemy finansowe okazały się nie do pokonania. Zebranie liczącego 100 milionów koron budżetu było niewykonalne. Jedyną pozostałością po tym projekcie jest kilkuminutowa kombinowana etiuda z 1996 roku zatytułowana Golem.

[51] Film Jandourka ma dwie wersje: kinową, prezentowaną pod tytułem Maharal - Tajemství talismanu (w Polsce pokazywała ją w 2010 roku TV Puls jako Maharal - tajemnica talizmanu) oraz telewizyjną, złożoną w pięciu półgodzinnych odcinków. [52] W dość krytycznej recenzji Kamil Fila nie dostrzegł fantastycznych walorów Koziho príbehu, napisał natomiast, że nie spełnia on żadnych kryteriów, jakie stawia się pełnometrażowym, animowanym filmom familijnym - nie jest ani disnejowskim musicalem, nie jest też jego parodią w stylu Shreka ani pixarowskim hołdem dla gatunku: „wybór własnej «czeskiej drogi» okazał się bardziej świadectwem całkowitej nieporadności niż twórczej wizji”, patrz. K. Fila, Kozí príbeh - Pověsti stare Prahy dílo kulturních barbarü, „Cinepur” 2008, nr 60, s. 34. [53] I. Adamovič, Př́sliby českého fantastického filmu, „Ikarie” 2005, nr 7, s. 35. 
Adamovič I., Př́sliby českého fantastického filmu, „Ikarie” 2005, nr 7

Benešová M., Tematické proměny ve filmech pro dĕti, „Film a doba” 1970, nr 6

Benešová M., Zápas o tvar. K životnímu jubileu narodního umělce Karla Zemana, „Film a doba” 1970, nr 12

Březina V. Lexikon českého filmu. 2000 filmů 1930-1996, Praha 1996

Černík M., 35 českých filmowych režisérů očima Zdeňka Svěráka, Jiřího Suchého, Květy Fialové, Radka Brzobohatého a v karykaturach Michala Černíka, Praha 2010

Dědinová T., Křeček J., Jak je na tom současná česká fantastika? Hledání hranic žánru a čtenáře, „Host. Měsíčník pro literaturu a čtenáře” 2018, nr 4

Encyklopedie literatury science fiction, sestavili Ondřej Neff, Jaroslav Olša jr, Praha 1995

Fila K., Kozí príbeh - Pověsti stare Prahy dílo kulturních barbarů, „Cinepur” 2008, nr 60

Gotthardt P., Skutečný stroj času. Scenáristické postupy v českých sci-fi filmech mezi lety 1918-1989. Disertační prace, Vedoucí práce: prof. Mgr. Jan Gogola, Divadelní fakulta Janáčková akademie múzických umění, Brno 2015

Guzek M., Jak kino czechosłowackie detonowało bombę atomowa, czyli o czym opowiada film Jindřicha Poláka Jutro wstanę rano i oparzę się herbatą, „Przegląd Humanistyczny" 2017, nr 1

Holčák L., Vladimír Menšík a jeho filmy, Ostrava 2015

Hrbas J., Karel Zeman. Pưvab chlepecké romantiky I, „Film a doba” 1974, nr 1

Hrudka L., Cesta do pravěku (O natáčení nového loutkového filmu), „Rudé právo” 1953, nr 227

Hudec Z., Novobilská A., Filmová komedie, [w:] Panorama českého filmu, (sest.) L. Ptáček, Olomouc 2000

Janáček P., Vědecká fantastika, [w:] Dějiny české literatury 1945-1989, III. 1958-1969, red. P. Janáček, Praha 2008

Jelinková E., Vím, že se zítra opařím čajem, „Kino” 1976, nr 20

Joneš A., Vo fantastickej rakete. O filme Jindřicha Poláka Zitra vstanu a opařim sa čajem, „Film a divadlo” 1976, nr 17

Kliment J., Nová československá filmová komedie. Čaj ne zrovna nejsilnějši, „Rudé právo" 1977, nr 200

Kliment, J., Polský důkaz v Karlových Varech, „Rudé právo” 1970, nr 269

Kliment J., Pro dobrou náladu, „Rudé právo” 1970, nr 48

Kopal P., Normalizace - deformace - dekadence. Několik drobnych poznámek o filmovém a televizním Monstru (1970-1990) [w:] Film a dějiny 4. Normalizace, red. P. Kopal, Praha 2014

Kopal P. (red.), Král Šumavy komunistický thriller, Praha 2019

Ládek J., Pavelka R., Encyklopedie komiksu v Československu 1945-1989, Praha 2010

Levý J., Českoslovenští filmoví režiséri sedmdesátých let, Praha 1983

Linhart L., E.F. Burian \& film, „Film a doba” 1970, nr 2

Loska K., Encyklopedia filmu science fiction, Kraków 2004

Lukeš J., Diagnózy času. Český a slovenský poválečný film (1945-2012), Praha 2013

Moc J., Seriály od A do Z. Lexikon českých serialů, Praha 2009

Pitera Z., Wyprawa w przeszłość, „Film” 1956, nr 50

Pospiš R., Dobrodružná cesta za miznúcim svetom, „film.sk” 2005, nr 5

Puls nekonečna. Kronika české science fiction 2. Od Vladimíra Babuly k Alexandru

Kramerovi, sestavil I. Adamovič, Praha 2011

Rohál R, Krasavci filmového nebe, Praha 2009

Sever P., Trochu prekomplikované, „Film a divadlo” 1977, nr 17

Slanina O., Poutník svètem fatazie, Praha 2018

Slanina O., Slavná česká filmová klasika, Praha 2013 
Slavik B., Jak w žanrovém filmu nevidĕt všudypřitomnost kopie... - Současné jihokorejské sci-fi na pozadi filozofie diference, „Film a doba” 2019, nr 4

Sluka J. (red.), Zdeňek Burian. Na vlnĕ dobrodružství. Katalog $k$ vystavě Zdeňka Buriana v Obecním doměv Praze 12 února 2013 - 19 března 2013, Praha 2013 Szczepanik P., Továrna Barrandov. Svĕt filmařů a politická moc 1945-1970, Praha 2016

Šorel V., Tvrz, Praha 2016

Toman V., Kocián M., Bican V., IKS. Strážci času, Velké Př́ilepy 2018

Tunys L, Hvĕzdy, které nezhasnou aneb Jak jsem je poznal, Praha 2012

Ulík K., Lubomír Lipský a jeho bratr Oldřich, Praha 2011

Vagaday J., Zabil jsem Einsteina, panové aneb nová science-fiction pánů Nasvadby, Macourka, Lipskégo, „Kino” 1969, nr 21

Velká kniha komiksu II, sestavil J. Buchal, Praha 2002

Wyprawa w przeszłość, „Filmowy Serwis Prasowy” 1953, nr 11

Zemanová L., Zemanová Spaleny L., Karel Zeman a jeho kouzelný svĕt, Brno 2015

Žka [Jiří Nožka], Nahlédli jsme do atelieru, „Svĕt v obrazech” 1954, nr 12 